\title{
Astma viena, fenotipų daug. Kaip parinkti tinkamiausią gydymą?
}

\author{
Virginija Kalinauskaitė-Žukauskè \\ LSMU MA Pulmonologijos klinika
}

Astmos gydymo tikslai ilgus dešimtmečius išlieka tie patys, tačiau gydymo parinkimo taktika atsirandant vis naujiems klinikinių tyrimų duomenims kinta. Pastaruoju metu pagrindinis rodiklis, lemiantis gydymo efektyvumo vertinimą ir jo korekcijų poreikį, yra astmos simptomų kontrolè. Nors vaistų astmai gydyti yra labai daug, vis dar nemažai sergančiujų patiria nekontroliuojamos astmos simptomus. Kaip vienas pagrindinių sunkumu, kodèl nepavyksta valdyti ligos eigos, i̇vardijama pati astmos patogenezè tai kompleksinẻ ir heterogeninė liga, turinti gausybę skirtingų fenotipu, pasižyminčių ir patogeneziniais ypatumais, skirtingais klinikiniais simptomais, jų sunkumu ir nevienodu atsaku į skiriamą gydymą. Siekiant maksimaliai efektyviai gydyti konkretaus paciento astmą, svarbu suprasti egzistuojančią skirtingų ligos fenotipų ivairovę, išmanyti patogenezinius jų mechanizmus ir skirtumus.

\section{SMULKIŲJŲ KVĖPAVIMO TAKŲ SVARBA}

Astma patogeneziškai apibrèžiama nuolatiniu kvėpavimo takų uždegimu ir nuolat vykstančia pastarųjų remodeliacija. Pats terminas astma apibūdina klinikini sindromą, apimantị ịvairius astmos fenotipus ir endotipus, kuriems būdingi skirtingi klinikiniai požymiai ar mechanizmai, nevienoda reakcija i gydymą. Todèl siekiama, kad kiekvienam ligoniui būtu skiriamas būtent jam tinkamiausias gydymas. Patologai jau seniai nustatè, kad, sergant astma, pažeidžiami ne vien stambieji, bet ir smulkieji kvèpavimo takai, apie kuriu pažeidimo svarbą aktyviai diskutuoti pradèta tik visai neseniai dèl ribotu galimybiư juos pasiekti ir ištirti, standartizuotu smulkiụjų kvejpavimo takų pokyčiu vertinimo kriterijų stokos. Pritaikius ivvairias fiziologines technikos priemones, tik pastarąji dešimtmeti pavyko ivvertinti periferiniu kvejpavimo takų būklę sergant astma ir spręsti apie skiriamu vaistu poveikị jiems.

Smulkiaisiais iprasta vadinti siauresnius nei $2 \mathrm{~mm}$ vidinio skersmens kvėpavimo takus. Dabar pripažįstama, kad sergant astma būtent smulkieji kvejpavimo takai ir yra pagrindine vieta, kur fiziologiškai ribojamas oro srautas. Pastarųjų disfunkcija sergant sunkia astma yra akivaizdi, daugeja įrodymu ir lengvesnès ligos eigos atvejais. Apatiniu kvèpavimo takų uždegimas ir fiziologinè disfunkcija (apimant ir smulkiuosius kvejpavimo takus) įrodyti esant ir skirtingiems astmos fenotipams, kaip an- tai: naktį pasireiškiančiai astmai, fizinio krūvio sukeltai astmai, alerginei astmai. Neseniai atlikta apžvalga parodè, kad smulkiụjų kvèpavimo taku pažeidimas gali būti ypač svarbus ir kitiems ligos fenotipams, pavyzdžiui, pacientams, sergantiems sunkia astma, turintiems dideli ligos „stažą“, senyvo amžiaus asmenims ir rūkantiesiems. Iškelta hipotezè, kad tik itin smulkios inhaliuojamụjų vaistų dalelès gali užtikrinti adekvatụ vaisto pasiskirstymą visame bronchų medyje ir taip pagerinti ventiliacinę kvèpavimo funkciją, suteikiant ir papildomą klinikinę naudą - geresnę astmos simptomu kontrolę palyginti su vaistų formulemis, kurios i kvepavimo takus ikvepiamos stambesnių daleliụ pavidalu.

\section{REALAUS GYVENIMO \\ TYRIMAS ITIN SMULKIUU \\ DALELIU BEKLOMETAZONO DIPROPIONATO IR FORMOTEROLIO DERINIO (BDP/F) VEIKSMINGUMUI IVERTINTI}

Išties geras astmos gydymo inhaliuojamaisiais gliukokortikoidais (IGK) ir ilgai veikiančiais $\beta$-2 agonistais (IVBA) veiksmingumas irodytas tiek klinikiniais tyrimais, tiek klinikineje praktikoje. Gydymas šių vaistų deriniu sumažina stacionarinio gydymo dažnumą ir mirštamumą nuo astmos.

Šiais metais publikuoti realaus gyvenimo perspektyviojo neintervencinio daugiacentrio (55 tyrimo centrai) stebéjimo tyrimo rezultatai. Tyrime ypatingas dèmesys skirtas suaugusiụjų, suskirstytụ i pogrupius pa- gal fenotipus dominuojant smulkiųju kvépavimo taku pažeidimui astmai gydyti itin smulkiomis BDP/F dalelèmis (pvz.: atkreipiant dèmesi i rūkymo ipročius, ligos trukmę, oro spąstus). Sio tyrimo tikslas buvo gauti detalesniu duomenu apie vaisto toleravimą, veiksmingumą gydant astmos simptomus ir kontroliuojant ligos eigą, vertinant galimą papildomą $\mathrm{BDP} / \mathrm{F}$ klinikinę naudą skiriant vaistą itin smulkiu ikvepiamụju daleliụ pavidale. Tyrime pacientams buvo skiriama fiksuota $\mathrm{BDP} / \mathrm{F}$ derinio dozé $(100 / 6 \mu \mathrm{g})$, ikvepiant po $1-2$ inhaliacijas 2 kartus per dieną 12 savaičiuc. Vertintas maksimalus iškvejpimo srovès greitis (PEF, angl. peak expiratory flow), forsuoto iškvèpimo tūris per pirmą sekundę (FEV1, angl. forced expiratory volume in one second), forsuota gyvybinè plaučiu talpa (FVC, angl. forced vital capacity), dieniniai astmos simptomai, astmos kontrolè ir astmos simptomu sunkumas (balais) bendroje populiacijoje ir skirtinguose pogrupiuose. Vertinimas atliktas trimis etapais - pradinio vizito metu, 4-8 ir 12-tą gydymo savaitę.

I tyrimą itraukta 213 pacientų, kurie sirgo astma ir turejo indikacijų būti gydomi IGK/IVBA deriniais. Itraukimo i tyrimą kriterijai buvo pasirinkti atsižvelgiant ị vaistinio preparato charakteristikų santraukoje esančias indikacijas, kontraindikacijas, specialias atsargumo priemones. Tyrime galèjo dalyvauti tik iki tol BDP/F deriniu negydyti asmenys. Stebètas apytiksliai vienodas tiriamụju pasiskirstymas pagal lyti 
(49,1 proc. moterys). Nerūkantys asmenys sudarè didžiąją dalị (53,1 proc.), buvę (23 proc.) ar esami rūkoriai (23,9 proc.) sudaré po ketvirtadali bendro tiriamųjų skaičiaus. 53,2 proc. rūkančiųjų turèjo ne mažesni kaip 20 metų rūkymo stažą. Apie 40 proc. tiriamųju ivvardijo ligos trukmę ilgesnę nei 10 metų. Daugiau nei 60 proc. tiriamųuc maksimali ikvėpimo srovè (angl. peak inspiratory flow - PIF) buvo mažesnè kaip $60 \mathrm{l} / \mathrm{min}$.

\section{Gauti tyrimo rezultatai svarbūs dviem aspektais:}

Bendrosios populiacijos pacientu gydymas itin smulkiomis BDP/F dalelèmis lėmé ženkliai geresnę astmos kontrolę (gerai kontroliuojamos astmos padaugejo nuo 6,1 proc. iki 66,3 proc.; $\mathrm{p}<0,001$; ženkliai sumažèjo nekontroliuojamos astmos atvejų - 70,3 proc., palyginti su 10,0 proc.; $\mathrm{p}<0,001$ ), plaučių funkciją, simptomų sumažèjimą, mažesnị greito veikimo simptominių vaistų poreikị. Gydymas BDP/F deriniu taip pat buvo susijęs su retesniais astmos priepuoliais ir lengvesniais ligos simptomais.

Akivaizdūs teigiami gydymo $\mathrm{BDP} / \mathrm{F}$ rezultatai stebeti ir pacientu pogrupiuose, priskiriamuose ryškių pokyčiu smulkiuosiuose kvépavimo takuose fenotipui (rūkantiems, astma sergantiems $>10$ metu ir pacientams su oro spąstais, kai FVC $<80$ proc.). Pastebėtas astmos simptomų susilpnejjimas visuose pogrupiuose, gydant $\mathrm{BDP} / \mathrm{F}$ deriniu ir reikšmingai nepriklausantis nuo fenotipo yra tarsi ịrodymas apie vaisto teigiamą poveikị sergančiųjų gyvenimo kokybei.

Norint užkirsti kelią astmos eigos sunkejjimui ilgainiui, gyvybiškai svarbu skirti kaip imanoma efektyvesni ir konkrečiam pacientui labiausiai tinkamą gydymą. Fiksuotuc dozių beklometazono dipropionato ir formoterolio (BDP/F, Foster ${ }^{\circ}$ ) 100/6 $\mu \mathrm{g}$ derinys dèl itin smulkiu ikvepiamo vaisto daleliuc pasižymi gera vaisto dalelių depozicija ir nuoseklesniu gydomuoju poveikiu visame bronchu medyje, klinikiniu aspektu - geresne astmos simptomu kontrole ir gyvenimo kokybe, lyginant su kitais IGK/IVBA deriniais, ikvepiamais per dideles vaistu daleles formuojančius inhaliatorius. Neseniai įrodytas ir itin smulkiu daleliuc BDP/F derinio, skiriamo tiek palaikomajam gydymui, tiek simptomams slopinti (MART metodika) efektyvumas nutolinant pirmą sunkų astmos paūmejjimą sergant nekontroliuojama astma. Nustatyta, kad skiriant BDP/F MART metodika taip pat ženkliai sumažèjo ir bendras metinis sunkių astmos paūmèjimų dažnis, suretėjo sisteminių gliukokortikoidu bei stacionarinio gydymo, skubios pagalbos poreikio atvejų.

\section{RŪKYMAS IR ASTMA}

Yra žinoma, kad cigarečių dūmai sukelia periferinių kvejpavimo taku anomalijas, astma sergantiems ir rūkantiems asmenims sparčiau blogèja plaučiu funkcija, dažnesni ligos paūmèjimai, didesnè nekontroliuojamos astmos tikimybè net tada, kai gydoma pagal rekomendacijas, didesnis stacionarinio gydymo poreikis. Kokie konkretūs patofiziologiniai mechanizmai atsakingi už sutrikusi atsaką i skiriamą gydymą astma sergantiems ir rūkantiems asmenims dar nèra aiškūs. Manoma, kad skiriamo gydymo efektyvumą ribojantis veiksnys yra nepakankamas inhaliuojamųju vaistų kiekis periferiniuose smulkiuosiuose kvejpavimo takuose. Plačiai diskutuojama apie kelis mechanizmus, galinčius turèti ịtakos rūkančių ir astma sergančių pacientu gydymui, - dèl rūkymo pakitę kvépavimo takų uždegimo procesai, ypač smulkiuosiuose kvẻpavimo takuose, sutrikęs receptorių jautrumas IGK. Paskelbti duomenys, kad IGK veiksmingumas aktyviai rūkantiems asmenims statistiškai reikšmingai rečiau lemia plaučių funkcijos pagerèjimą, lyginant su nerūkančiais astma sergančiais pacientais (išvada suformuluota vertinant 3 savaičių trukmès gydymo inhaliuojamuoju flutikazonu duomenis). Sutrikęs rūkalių, sergančių astma, atsakas it gydymą IGK gali būti aiškinamas dominuojančiu neutrofiliniu kvėpavimo takų uždegimu ar sutrikusia genų, atsakingų už steroidinių receptorių atsaką, veikla.

Realaus gyvenimo tyrimo su itin smulkiomis BDP/F ikvepiamosiomis dalelèmis rezultatai parodè, kad astmos gydymo BDP/F atsakas buvo panašus tiek mažesni ( $<20$ pakmečiu $)$, tiek didesni ( $\geq 20$ pakmečių) rūkymo stažą turintiems rūkoriams. Nors pradinio vizito metu plaučių funkciją apibūdinantys rodikliai buvo kiek prastesni buvusiems rūkoriams, tačiau skirtas gydymas BDP/F deriniu buvo vienodai veiksmingas lyginant su kitu grupių tiriamaisiais. Nerūkiusiems asmenims stebėtas ženklesnis astmos simptomų kontrolès pagerejjimas (75,2 proc. palyginti su 58,0 proc. rūkaliu ir 54,2 proc. rūkusiu anksčiau); 30 proc. dabar rūkančių ir anksčiau rūkiusių asmenų gydymo BDP/F deriniu pabaigoje pasiekè dalinę astmos simptomų kontro- lę. Po 12 gydymo savaičių, lyginant su pradiniu vizitu, pastebètas reikšmingas plaučių funkcijos parametrų pagerèjimas ir rūkantiems asmenims (1 lentelé; $\mathrm{p}<0,01$ visiems kintamiesiems). Taip pat tyrime nustatyta, kad rūkantiems ir BDP/F deriniu gydomiems asmenims ženkliai pagerèja astmos simptomai, kaip antai kosulys, spaudimas krūtinèje, švokštimas ir dusulys (pav.). Kosulys, vertinant balais, sumažejo nuo 1,6 gydymo pradžioje iki 0,4 12-tą gydymo $\mathrm{BDP} / \mathrm{F}$ savaitę, krūtinès spaudimas nuo 1,8 iki 0,6 , švokštimas - nuo 1,4 iki 0,3 , dusulys - nuo 1,3 iki 0,2 balo ( $\mathrm{p}<0,01$ visiems palyginimams).

Taigi realaus gyvenimo tyrimo su itin smulkiomis BDP/F ikvepiamosiomis dalelèmis rezultatai parodé, kad astmos kontrolé, ženklus simptomuc pagerẻjimas stebėtas tiek rūkantiems, tiek nerūkantiems pacientams. Kadangi i tyrimą įtraukti pacientai iki tol buvo gydyti vaistais, inhaliuojamais per dideles daleles formuojančius inhaliatorius, galima galvoti, kad gydymas itin smulkiomis vaistų dalelèmis tikslingai veikia ir smulkiuosius kvejpavimo takus, taip padidindamas vaisto veiksmingumą ir rūkantiems astma sergantiesiems, kuriems gydymas didelèmis vaistu dalelèmis buvo mažiau veiksmingas.

Neseniai paskelbti ir dar vieno stebejjimo tyrimo rezultatai. Vertintas gydymo veiksmingumas skiriant inhaliuojamuosius vaistus smulkias daleles suformuojančiais inhaliatoriais, lyginant su didelių dalelių ikvepiamųjų vaistu formomis, atskirai vertinant klinikinius rezultatus ir rūkančių astma sergančiųjų pogrupyje. Pirmoji vertinamoji baigtis buvo rūkančių ir astma sergančių asmenų smulkiųjų kvėpavimo taku sutrikusios funkcijos ìvertinimas, taip pat papildomai vertinant klinikini efektą pakeitus standartini astmos gydymą i vaistus, kurie ịkvepiami per itin smulkias vaisto daleles formuojančius inhaliatorius. Vaistų keitimai atlikti paskiriant adekvačias iki tol vartotiems vaistams dozes (pacientams, kurie iki prasidedant tyrimui ¡kvèpdavo didelio dydžio IGK daleles, gydymas buvo keičiamas ị itin smulkių dalelių beklometazono dipropionatą, o vartojusiems IGK/IVBA derini - $\mathfrak{i}$ itin smulkiu daleliu BDP/F). Pirminè vertinamoji baigtis buvo išskiriamo azoto (dN2) matavimas iškvepiamame ore pradinio vizito metu ir gydymo eigoje. Reikšmingai didesnis dN2 buvo randamas rūkantiems, palyginti su nerūkančiais asmenimis, nurodant sutrikusia ventiliaciją smulkiuosiuose kvėpavimo takuose. 3 mėnesiu trukmès astmos 
1 lentelè. Demografiniai duomenys ir klinikiniai rezultatai praejus 12 savaičių nuo gydymo beklometazono dipropionato ir formoterolio deriniu pradžios (pagal rūkymo ipročius)

\begin{tabular}{|c|c|c|c|c|c|c|}
\hline 1. Demografiniai duomenys & \multicolumn{2}{|c|}{ Rūkantys $(\mathrm{n}=50)$} & \multicolumn{2}{|c|}{ Buvę rūkoriai $[n=48]$} & \multicolumn{2}{|c|}{ Nerūkę $(\mathrm{n}=111)$} \\
\hline Amžiaus vidurkis, metai $\pm \mathrm{SN}$ & $44,3 \pm 12,8$ & & $54,9 \pm 14,4$ & & $49,2 \pm 17,8$ & \\
\hline Moterys/vyrai, proc. & $48 / 52$ & & $40 / 60$ & & $57 / 43$ & \\
\hline Rūkoriai ( $\geq 20$ pakmečių), proc. & 53,2 & & - & & - & \\
\hline 2. Rezultatai & $\begin{array}{l}\text { Pradinis } \\
\text { vizitas }\end{array}$ & $\begin{array}{l}\text { Po } 12 \\
\text { savaičių* }\end{array}$ & Pradinis vizitas & $\begin{array}{l}\text { Po } 12 \\
\text { savaičių* }\end{array}$ & $\begin{array}{l}\text { Pradinis } \\
\text { vizitas }\end{array}$ & $\begin{array}{l}\text { Po } 12 \\
\text { savaičių* }\end{array}$ \\
\hline \multicolumn{7}{|l|}{ Astmos kontrolès lygis, proc. pacientų ${ }^{\mathrm{a}}$} \\
\hline $\begin{array}{l}\text { Gerai } \\
\text { kontroliuojama }\end{array}$ & 10,0 & 58,0 & 4,3 & 54,2 & 4,5 & 75,2 \\
\hline $\begin{array}{l}\text { Iš dalies } \\
\text { kontroliuojama }\end{array}$ & 18,0 & 32,0 & 17,0 & 33,3 & 29,7 & 16,5 \\
\hline Nekontroliuojama & 72,0 & 10,0 & 78,7 & 12,5 & 65,8 & 8,3 \\
\hline $\begin{array}{l}\text { Simptomu sustiprèjimas dienos metu/sav.; } \\
\text { vidurkis } \pm \text { SN }\end{array}$ & $2,1 \pm 3,3$ & $0,1 \pm 0,5$ & $1,5 \pm 1,9$ & $0,2 \pm 0,5$ & $1,7 \pm 2,7$ & $0,2 \pm 1,0$ \\
\hline $\begin{array}{l}\text { Naktinių simptomu sustiprejimas/sav; } \\
\text { vidurkis } \pm \text { SN }\end{array}$ & $1,3 \pm 2,0$ & $0,1 \pm 0,3$ & $1,5 \pm 2,1$ & $0,1 \pm 0,3$ & $1,1 \pm 1,5$ & $0,1 \pm 0,5$ \\
\hline $\begin{array}{l}\text { Astmos simptomų sunkumas, balu } \\
\text { vidurkis } \pm \text { SN }\end{array}$ & $1,5 \pm 0,7$ & $0,4 \pm 0,4$ & $1,7 \pm 0,7$ & $0,4 \pm 0,4$ & $1,5 \pm 0,7$ & $0,3 \pm 0,4$ \\
\hline $\begin{array}{l}\text { Pacientai, kurie kiekvieną savaitę patiria } \\
\text { astmos paūmèjimą, proc. }\end{array}$ & 18,2 & 2,4 & 15,4 & 0,0 & 13,3 & 1,2 \\
\hline $\begin{array}{l}\text { Pacientai, vartojantys greitos pagalbos simp- } \\
\text { tomus slopinančius vaistus }>2 \mathrm{k} \text {,/sav., proc. }\end{array}$ & 67,7 & 7,9 & 70,3 & 27,5 & 71,9 & 10,8 \\
\hline Dieniniai simptomai $>2 \mathrm{k}, /$ sav., proc. & 77,8 & 13,5 & 77,8 & 7,9 & 75,0 & 11,4 \\
\hline $\begin{array}{l}\text { Pacientai, kuriems dèl astmos buvo } \\
\text { apribotas fizinis aktyvumas, proc. }\end{array}$ & 73,7 & 23,8 & 75,0 & 16,7 & 76,9 & 7,1 \\
\hline Naktiniai simptomai, proc. & 61,1 & 2,4 & 66,7 & 2,5 & 66,7 & 4,8 \\
\hline Pacientai, kurių FEV1<80 proc. b. d. & 81,3 & 37,1 & 92,1 & 36,1 & 85,5 & 15,5 \\
\hline FEV1, l (proc. b. d. \pm SN) & $\begin{array}{l}2,5 \pm 1,0 \\
(80,5 \pm 35,8)\end{array}$ & $\begin{array}{l}3,4 \pm 2,2 \\
(107,7 \pm 79,1)\end{array}$ & $\begin{array}{l}2,2 \pm 1,0 \\
(73,6 \pm 29,1)\end{array}$ & $\begin{array}{l}2,9 \pm 1,0 \\
(96,4 \pm 38,4)\end{array}$ & $\begin{array}{l}2,7 \pm 2,1 \\
(92,1 \pm 72,5)\end{array}$ & $\begin{array}{l}3,1 \pm 1,6 \\
(103,1 \pm 54,8)\end{array}$ \\
\hline PEF, $1 /$ min. $( \pm \mathrm{SN})$ & $323 \pm 126$ & $393 \pm 135$ & $287 \pm 124$ & $357 \pm 138$ & $321 \pm 133$ & $376 \pm 130$ \\
\hline FVC $1 \pm \mathrm{SN}$ (proc. b. d. $\pm \mathrm{SN}$ ) & $\begin{array}{l}3,3 \pm 1,3 \\
(89,0 \pm 39,2)\end{array}$ & $\begin{array}{l}3,9 \pm 1,3 \\
(104,6 \pm 40,96)\end{array}$ & $\begin{array}{l}3,0 \pm 1,1 \\
(80,6 \pm 28,2)\end{array}$ & $\begin{array}{l}3,5 \pm 1,0 \\
(94,3 \pm 22,6)\end{array}$ & $\begin{array}{l}3,4 \pm 1,5 \\
(91,5 \pm 34,8)\end{array}$ & $3,9 \pm 1,9$ \\
\hline
\end{tabular}

SN - standartinis nuokrypis; FEV1 - forsuotas iškvèpimo tūris per pirmą sekundę; FVC - forsuota gyvybinè plaučių talpa; PEF - maksimalus iškvėpimo srovès greitis; b. d. - būtinojo dydžio; ${ }^{a-}$ Pagal GINA (angl. Global Initiative for Asthma Guidelines); "p<0.01 lyginant su pradiniu vizitu (porinis Studento t kriterijus).

gydymas smulkias ikvepiamo vaisto daleles formuojančiu inhaliatoriumi ženkliai sumažino dN2 ir kvėpavimo takų pasipriešinimą (rezistentiškumą) astma sergantiems rūkaliams.

\section{IGK/IVBA DERINIO \\ VEIKSMINGUMAS SKIRTINGOS ASTMOS TRUKMĖS ATVEJAIS}

Labai svarbu užkirsti kelią astmos paūmejjimams bei užtikrinti veiksmingą ilgos trukmès astmos gydymą ilgainiui. Tik keliuose klinikiniuose tyrimuose vertintas galimas ryšys tarp astmos nustatymo trukmès ir skiriamo gydymo efektyvumo, pateikiant išvadas, kad ventiliacinès plaučių funkcijos pagerèjimą atspindintys rodikliai gerokai didesni trumpiau sergantiems astma asmenims. Patofiziologiniai mechanizmai, galintys lemti tokị skirtingą gydymo atsaką, vis dar nèra iki galo žinomi; spéjama, kad jie yra susiję su nuolat vykstančiu nekontroliuojamu uždegimu ir kvėpavimo taku remodeliacija. I minèto realaus gyvenimo tyrimo tiriamųjų kohortą ittraukti skirtingą laiko tarpą astma sergantys asmenys. Pacientai su ilgesniu astmos „stažu“ (>10 metų)
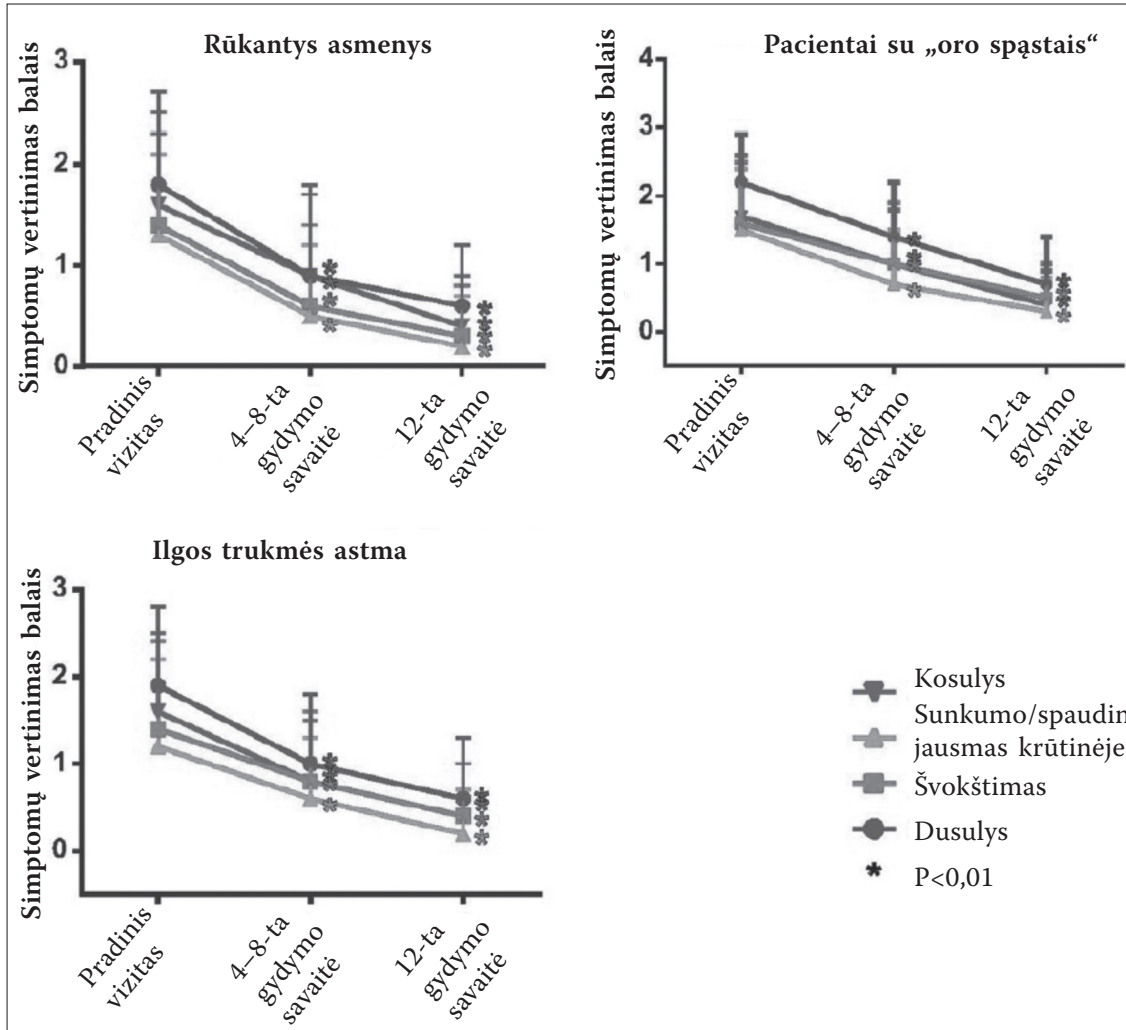

Pav. Astmos simptomy sunkumo vertinimas balais, esant skirtingiems ligos fenotipams. Simptomai vertinti 4 balu skaleje, kur 0 - nèra simptomu, o 3 - sunkūs, labai ryškūs simptomai. Rezultatai pateikiami kaip simptomy jvertinimo balais vidurkis \pm standartinis nuokrypis vartojant $\mathrm{BDP} / F$ derinj skirtingais laiko etapais, lyginant su vertinimu pradinio vizito metu 
2 lentelè. Demografiniai duomenys ir klinikiniai rezultatai praejjus 12 savaičių nuo gydymo beklometazono dipropionato ir formoterolio deriniu pradžios (pagal ligos trukmę)

\begin{tabular}{|c|c|c|}
\hline 1. Demografiniai duomenys & $\begin{array}{l}\text { Trumpa astmos trukmé } \\
(\leq 10 \text { metu })(n=128)\end{array}$ & $\begin{array}{l}\text { Ilga astmos trukmé } \\
(>10 \text { metuc) }(\mathrm{n}=83)\end{array}$ \\
\hline Amžiaus vidurkis, metai $\pm \mathrm{SN}$ & $44,8 \pm 16,0$ & $54,7 \pm 15,0$ \\
\hline Moterys/vyrai, proc. & $47 / 53$ & $58 / 42$ \\
\hline $\begin{array}{l}\text { Naujai nustatyta liga per } 1-5 \\
\text { metus/per } 5-10 \text { metuc /per }>10 \\
\text { metuc, proc. }\end{array}$ & $25 / 45 / 30 /-$ & $-/-/-/ 100$ \\
\hline Rūkantys/buvę rūkoriai/nerūkę, proc. & $26 / 20 / 54$ & $21 / 28 / 51$ \\
\hline 2. Rezultatai & $\begin{array}{l}\text { Pradinis } \\
\text { vizitas }\end{array}$ & $\begin{array}{l}\text { Po } 12 \\
\text { savaičių* }\end{array}$ \\
\hline
\end{tabular}

Astmos kontrolès lygis, proc.

pacientųa

\begin{tabular}{|c|c|c|c|c|}
\hline Gerai kontroliuojama & 6,3 & 72,7 & 4,8 & 55,6 \\
\hline Iš dalies kontroliuojama & 25,2 & 21.1 & 20,5 & 28,4 \\
\hline Nekontroliuojama & 68,5 & 6,3 & 74,7 & 16,0 \\
\hline $\begin{array}{l}\text { Simptomú sustiprèjimas dieną/ } \\
\text { sav.; vidurkis } \pm \text { SN }\end{array}$ & $1,5 \pm 2,2$ & $0,1 \pm 0,5$ & $2,2 \pm 3,3$ & $0,3 \pm 1,1$ \\
\hline $\begin{array}{l}\text { Naktiniu simptomu sustiprèjimas/ } \\
\text { sav.; vidurkis } \pm \text { SN }\end{array}$ & $1,0 \pm 1,5$ & $0,1 \pm 0,3$ & $1,6 \pm 2,2$ & $0,1 \pm 0,5$ \\
\hline $\begin{array}{l}\text { Astmos simptomu sunkumas, balu } \\
\text { vidurkis } \pm \text { SN }\end{array}$ & $1,6 \pm 0,7$ & $0,3 \pm 0,4$ & $1,5 \pm 0,7$ & $0,4 \pm 0,4$ \\
\hline $\begin{array}{l}\text { Pacientai, kurie kiekvieną savaitę } \\
\text { patiria astmos paūmèjimą, proc. }\end{array}$ & 16,0 & 1,9 & 14,3 & 0,0 \\
\hline $\begin{array}{l}\text { Pacientai, vartojantys greitos } \\
\text { pagalbos simptomus slopinančius } \\
\text { vaistus }>2 \mathrm{k} . / \mathrm{sav} \text {.; proc. }\end{array}$ & 63,8 & 9,2 & 80,4 & 22,1 \\
\hline Dieniniai simptomai >2 k./sav.; proc. & 73,5 & 10,2 & 81,5 & 11,8 \\
\hline $\begin{array}{l}\text { Pacientai, kuriems dèl astmos buvo } \\
\text { apribotas fizinis aktyvumas, proc. }\end{array}$ & 75.0 & 10.3 & 76.2 & 18.1 \\
\hline Naktiniai simptomai; proc. & 64,2 & 3,2 & 66,1 & 4,1 \\
\hline Pacientai, kuriụ FEV1<80 proc. b. d. & 88,1 & 21,3 & 83,9 & 31,7 \\
\hline FEV1, 1 (proc. b. d. $\pm \mathrm{SN}$ ) & $\begin{array}{l}2,9 \pm 1,9 \\
(90,3 \pm 67,1)\end{array}$ & $\begin{array}{l}3,4 \pm 1,9 \\
(106,7 \pm 63,7)\end{array}$ & $\begin{array}{l}2,1 \pm 1,0 \\
(70,6 \pm 69,3)\end{array}$ & $\begin{array}{l}2,6 \pm 1,1 \\
(88,7 \pm 81,3)\end{array}$ \\
\hline PEF, $1 /$ min. $( \pm \mathrm{SN})$ & $327 \pm 117$ & $396 \pm 121$ & $294 \pm 145$ & $344 \pm 146$ \\
\hline$\overline{F V C} 1 \pm \mathrm{SN}$ (proc. b. d. $\pm \mathrm{SN}$ ) & $\begin{array}{l}3,6 \pm 1,4 \\
(93,8 \pm 35,6)\end{array}$ & $\begin{array}{l}4,2 \pm 1,7 \\
(107,8 \pm 42,1)\end{array}$ & $\begin{array}{l}2,8 \pm 1,2 \\
(81,2 \pm 31,5)\end{array}$ & $\begin{array}{l}3,3 \pm 1,2 \\
(95,1 \pm 35,4)\end{array}$ \\
\hline
\end{tabular}

SN - standartinis nuokrypis; FEV1 - forsuotas iškvėpimo tūris per pirmą sekundę; FVC - forsuota gyvybinė plaučiu talpa; PEF - maksimalus iškvejpimo srovės greitis; b. d. - būtinojo dydžio; ${ }^{a}$ - Pagal GINA (angl. Global Initiative for Asthma Guidelines); "p <0,01 lyginant su pradiniu vizitu (porinis Studento t kriterijus).

iprastai turi prastesnę plaučių funkciją, stebimos didesnio simptomams malšinti skirtų vaistų suvartojimo bei dažnesnių dieninių astmos simptomų tendencijos. Realaus gyvenimo tyrime nustatyta, kad skiriant $\mathrm{BDP} / \mathrm{F}$ visi minèti klinikiniai rodikliai (ventiliacinė plaučių funkcija, suvartojamu simptominiu vaistuc ir dieninių astmos simptomų kiekis) pagerejjo tiek trumpiau, tiek ilgiau sergantiesiems astma. Abiejose minètose grupèse stebètas astmos simptomuc kontrolès pagerëjimas atitinkamai 72,7 ir 55,6 proc. ( $p<0,01$ lyginant su pradiniu vizitu prieš paskiriant minètą IGK/IVBA derini). Gydant $\mathrm{BDP} / \mathrm{F}$ deriniu net ir ilgai astma sergantiems tiriamiesiems stebètas ventiliacinès plaučių funkcijos pagerejimas lyginant su pradiniu vizitu (2 lentelè, $p<0,01$ visiems kintamiesiems). Simptomų intensyvumą žymintys balai pakito taip: kosulio balas sumažèjo nuo 1,6 pradinio vizito metu iki 0,4 12-ta gydymo BDP/F savaitę; krūtinès spaudimo pojūtis atitinkamai nuo 1,9 iki 0,6 balo; švokštimas - nuo 1,4 iki 0,4 balų; dusulys - nuo 1,2 iki 0,2 b. ( $p<0,01$ visiems palyginimams) (pav.). Nustatyta, kad po skirto gydymo itin smulkiu daleliu BDP/F deriniu daugiau kaip pusei ilgai astma sergančiu tiriamųjų astmos simptomai tapo kontroliuojami vos per 12 savaičiu gydymo BDP/F, palyginti su mažiau nei 5 proc. pradinio vizito metu.

\section{ASTMA IR „ORO SPASTAI“}

Smulkiųjų kvėpavimo takų uždegimo ir remodeliacijos pokyčiai gali lemti kliniškai reikšmingą pastarųju susiaurejjimą ar net užsidarymą, o tai sukelia oro spąstus periferiniuose kvèpavimo takuose. Siekiant ịvertinti smulkiųjų kvėpavimo takų pažeidimą realaus gyvenimo sąlygomis naudotas FVC rodiklis. Pacientai, turintys oro spąstus (tyrime tai ìvardyta kaip FVC $<80$ proc. b. d.), paprastai pasiekia blogesnę astmos kontrolę. Tyrimo rezultatai parodè, kad gydymas itin smulkiomis BDP/F dalelèmis mažina oro spąstus: gydant $\mathrm{BDP} / \mathrm{F}$ deriniu FVC vertė susinormalizavo 83 proc. atvejų. Tyrimo duomenimis, su smulkiaisiais kvèpavimo takais susiję ligos komponentai (pvz.: naktiniai simptomai, oro spąstai) gydant $\mathrm{BDP} / \mathrm{F}$ per itin smulkias daleles formuojanti inhaliatorių kliniškai reikšmingai pagerejo. Nustatytas ir kliniškai reikšmingas astmos simptomų intensyvumo sumažejiimas lyginant su pradiniu vizitu ( $\mathrm{p}<0,01$ visiems palyginimams) (pav.). Po skirto gydymo BDP/F procentinè dalis pacientų, turinčių oro spąstus ir nekontroliuojamą astmą, sumažèjo nuo 83 iki 14 proc. Tai gali būti susiję su geresne vaisto dalelių depozicija periferiniuose kvėpavimo takuose, efektyvesniu uždegimo gydymu net ir smulkiuosiuose kvėpavimo takuose.

\section{APIBENDRINIMAS}

Pacientams, sergantiems astma, pagrindiniai gydymo tikslai yra kontroliuoti ligos simptomus, užkirsti kelią paūmejjimams, išlaikyti plaučiu funkciją, neribojant pacientui gyventi normalų aktyvų gyvenimą. Ilgus metus astmos gydymo rekomendacijos rèmési atsitiktiniuc imčiuc kontroliuojamųjuc tyrimų rezultatais, tačiau pastaruoju metu vis labiau telkiamas demesys $i$ realaus gyvenimo tyrimus, kadangi atsitiktinių imčiuc kontroliuojamujuc tyrimų duomenys paprastai gaunami iš specialiai atrinktuc, „vienodų“ pacientuc populiacijos ir neatsižvelgiama $i$ atskiru pogrupių ypatumus, pvz., rūkančiuosius, vyresnio amžiaus pacientus, pacientus, sergančius ivvairiomis gretutinèmis ligomis.

Neabejojama, kad persistuojantis uždegimo procesas sergantiesiems astma paliečia tiek stambiuosius, tiek smulkiuosius kvėpavimo takus. Labiausiai nutolusius smulkiuosius kvèpavimo takus pavyksta gydyti tik skiriant vaistus, galinčius dèl savo itin smulkių dalelių formos juos pasiekti. Atliktas realaus gyvenimo stebimasis tyrimas parodè, kad $\mathrm{BDP} / \mathrm{F}$ derinys ir inhaliatoriaus formuojamos itin smulkios veikliụjų medžiagų dalelès labai pagerina astmos kontrolę, palengvina astmos simptomus tiek bendroje populiacijoje, tiek konkrečiuose pacientuc pogrupiuose (vyresniems pacientams, turintiems „oro spąstus“, rūkantiems, ilgus metus sergantiems astma).

\section{LITERATŪRA}

1. Marth K, Spinola M, Kisiel J et al. Treatment response according to small airway phenotypes: a real-life observational study. Ther Adv Respir Dis, 2016, 10(3): 200-210.

2. Contoli M, Bellini F, Morandi L et al. Assessing smal airway impairment in mildto-moderate smoking airway impairment in mildto-moderate smoking asthmatic patients.European Respiratory Journal 2016; DOI: 10.1183/13993003.01708-2015. content/early/2016/02/11/13993003.01708-2015. 